\title{
The land claims issue and the Sámi - reflections on contemporary legal struggle
}

\section{Introduction}

In modern times we can observe a general process towards increasing culture-political awareness among peoples belonging to the Fourth World. In this process the question of land rights plays a superordinate role, as land rights constituted one of the fundamental elements embodied in the more inclusive legal comprehension of aboriginal rights. Closely connected to ecology, rights to land and water imply a primary condition for cultural viability and continuity. Areas of land traditionally occupied and long used, relatively undisturbed, by minorities with aboriginal status, such as the Sámi, are today subject to growing encroachments from the outside. The strongly contrasting interests of industrial societies frequently clash with the gentle, more cautious exploitation of renewable resources carried out by indigenous peoples within the same area. The issue of land rights is not actualized until such a collision makes it more difficult, or even impossible, for the indigenous people to continue their resource development in a traditional way. Without exaggeration it can be stated that the ethnic minority group will gradually experience conditions of ecological crisis, it will be more and more difficult to maintain resource development well-adjusted to seasonal changes of the year.

Some occupational segments of the Sámi population which are of vital importance to the cultural self-identification of the total ethnic group, are distinguished by fairly extensive land use patterns. Large, unobstructed territories are required regardless of whether the ecological adaptation is to reindeer pastoralism with some supplementary means of livehood or to varying forms of hunting and trapping, including fishing. The idea of land rights not only refers to definite areas of land one wishes to protect and transfer to future generations; it has just as much to do with rights to a specific way of life, an objective which is steadily more difficult to realize in the strained situation these people are facing at present. Under these circumstances the question of land rights has developed into a central ethnopolitical theme.

The claim to land rights concerns the right to survive culturally in spite of numerical weakness; thus making it possible for minority groups to resist an appreciable pressure towards assimilation. It is only recently that such claims have been formulated more explicitly by native peoples; in terms of legal history the concept of land rights, however, is a rather old phenomenon. In the following account I wish to examine diverse aspects of land rights, thereby pointing out the importance as well as the complexity of the phenomenon.

The Taxed Mountains Case, forming the core material on which my general argument is built, needs further explanation. This case was a legal contest between the Sámi and the Swedish state focusing on the issue of ownership rights to land and water in the South Sámi region of Swedish Lapland, County Jämtland. The controversy dealt with rights in principle and lasted for 15 years concluded when the Swedish Supreme Court handed down its final decision in 1981 (HD 1981). In the main, the outcome was unfavorable to the Sámi, all their claims were denied on legal grounds, which means that State ownership rights are confirmed. On the other hand, the verdict has great documentary value, the primary point of which refers to the affirmation in court of the actual strength of Sámi usufructuary rights and that they are founded on rights of immemorial usage. For the majority of Sámi, however, such juridical subtleties can in no way erase the conception that after such an extremely long litigation the Sámi remain losers of the dispute.

\section{Different aspects of land rights}

The Nation-State and the indigenous minority group regard the question of land rights rather differently. To the State in its role as adversary the problem refers exclusively to law, and it is a matter of finding which section in the existing system of law will open for a legal interpretation on which a court

Tom G. Svensson, Ethnographic Museum, University of Oslo, Fredriksgate 2, Oslo 1, Norway 
decision later on could be based. In two recent court cases, the Taxed Mountains Case in Sweden and the Alta Case in Norway, the courts, as well as the State carrying out the law suit, have chosen such a narrow definition of the situation in order to bring about a legal settlement in principle.

On the other hand, the Sámi have endeavored to introduce their views on land rights, which are far more comprehensive in comparison with narrow law of property, for instance. Certainly the concept of land rights has definite legal contents; consequently, the juridical aspects of this complicated matter cannot be neglected. Neither is it possible to attain a legal examination in court if these fundamental rules of the game are not obeyed. The legal arena is, however, constrained to be an instrument through which a more profound and extensive articulation about the subject matter "land rights" can occur. Once having entered the legal arena, therefore, it is vital to utilize the opportunity as much as possible to achieve a more Sámi-specific argumentation, i.e. in a skilled manner to manage the contents of ideas in the plea for legitimate claims, thereby extending the definition of the situation in the geatest possible way. In this extension it is necessary to move with great caution to avoid negative sanctions both from the court and the powerful opponent; the purpose is primarily to have all the actors accept a general conception of what is relevant for the legal contest in question.

To the Sámi it is crucial to emphasize the close connection between land rights and ecology. Improved land rights constitute for the Sámi a basic pre-requisite which makes it possible for them to continue developing natural resources in a way characteristic for their varying forms of life style. This necessitates attaining equilibrium in the ecosystem of which the Sámi are a part. Furthermore, land rights have to do with politics. The acquisition of self-determination, i.e. real power concerning their own affairs, is based on the possession of firm land rights. With such rights the development of resources can be controlled and at the same time the political and cultural autonomy will be strengthened. Without extremely strong land rights such autonomy will remain a chimera. Finally, the question of land rights could be considered a critical cultural issue. Effective land rights are essential for land-based indigenous people in order to maintain their cultural viability.

In any legal confrontation the above aspects are subordinate to the strict juridical argumentation. Therefore, they must be woven into the "juridical text" in covert terms, although they must be sufficiently explicit, to communicate the complete message.

Apart from the legal arena, the means of negotiation and of legislation represent two supplementary arenas in which the land rights issue can be exposed.
Real negotiations can hardly occur unless both parties involved, i.e. even the minority group, possess an adequate amount of power. So far the Sámi have not reached such a position. In this case comparison could be made with the Cree and the Inuit of Northern Quebec and their negotiations with the authorities in connection with the James Bay Hydro Power Project in 1975. The final agreement which was reached then was entirely conditioned by a previous court decision in favor of the Cree, the Malouf Case of 1973.

To bring about changes giving certain positive results, through the procedure of legislation is a process almost as demanding of time and effort as the one utilizing the legal apparatus. In Norway as well as in Sweden we are presently experiencing large, comprehensive investigations, assigned by Parliament, which are to examine all available materials dealing with the legal complexity of Sámi rights in order to work out proposals for new legislation. Ideally speaking these proposals are expected to meet the long-standing demands of the Sámi, among other things their claim to improved rights to land and water, demands so far repudiated by our courts. (The Taxed Mountains Case, The Swedish Supreme Court Decision 1981.)

\section{Diverse legal foundations related to land rights}

The legal frame of reference connected to land rights ought to be expressed more precisely. First, land rights have to do with customary law, which provides a weighty basis for legal argumentation. Codification through legislation presents another specification, whereas principles founded on international law completes the juridical platform on which land rights must be modelled.

With its links back to ancient times customary law is obviously the specification of land rights having the closest relation to aboriginal rights. Consequently, it is natural to introduce the following discussion with Sámi customary rights to land. Customary right reflects the people's own theory about territory as well as their conception of land rights. Customary right, therefore, is the legal aspect offering the most evident legitimacy for alleging native land claims.

The Sámi did not have to assert special territorial rights until they made the transition to reindeer pastoralism in a highly specialized form. It was not until this form of ecological adaptation was established that the Sámi began to exercise a more intensive use of the land which they occupied. In time this culture transformation coincided with increasing pressure from the outside, i.e. from the middle of the 16th century on. Among the Sámi, as well as many schol- 


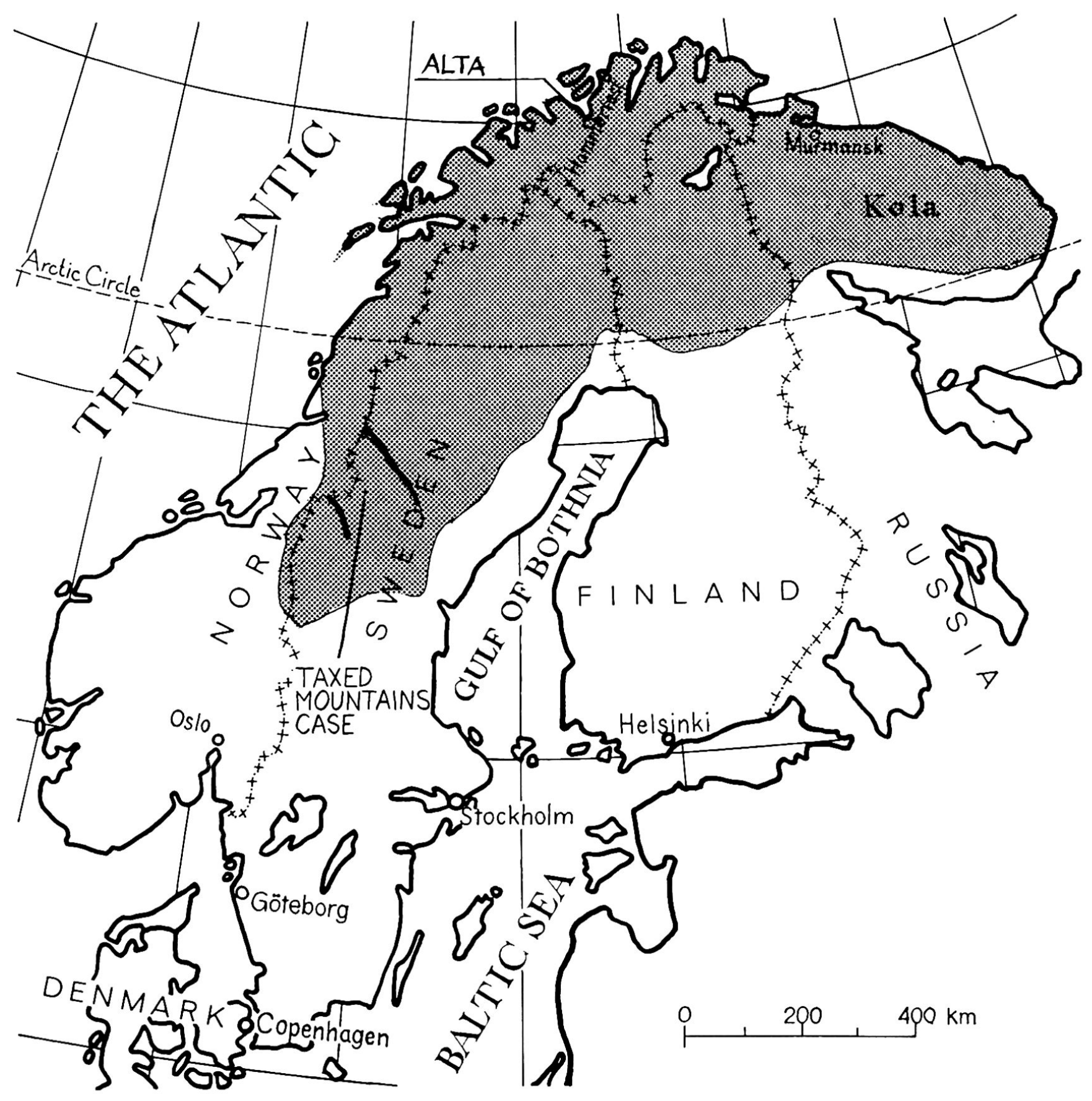

Fig. 1 Map showing present geographical distribution of the Sámi

ars, a general view is maintained that the Sámi formerly possessed absolute rights concerning management of land and water, characterized by collective ownership of land in contrast to the individual ownership rights prevailing in the larger society. It is the cooperative herding unit, sii'da, that is considered the proper owner of the sii'da territory, whereas individual members have strong usufructuary rights within its boundaries. This right of land management became problematic from the moment the larger society started to exert demands for exploitation of alternative non-renewable resources within the same territory. The authority of the sii'da council decreased at the same pace as the dominant society with its structural strength began to assert itself more and more on the original sii'da territories.

Later the local courts, häradsrätten, rather than the siida council became the authority officially assigned to solve legal contests, though still with Sámi participation. Not infrequently these court deci- 
sions rested on Sámi customary rights and original conception of territory based on oral tradition. Especially for the Taxed Mountains Case the Sámi party had an expert in legal history engaged to examine a most extensive body of court records concerning the period 1645-1848. (PRAwITZ, 1966-67). This material clearly indicates that principles related to rights of inheritance and birth rights, or rights of decendency, as a rule constituted the foundation on which internal conflicts concerning land rights claims on the taxed mountains were resolved. This agrees with Sámi legal views and sociocultural norms as we know them from NorthSámi and East-Sámi regions. (See e.g. E. SOLEM, 1933 and I. RUONG, 1936. Compare also the recent study by K. KORPIJAAKKO, 1985: 1-2).

The question of land rights for the reindeer pastoralist Sámi must also be viewed in relation to the interdependency between the three component parts, pasture - reindeer - personnel, an ecological perspective for analysis introduced by Robert Paine (Paine, 1972). The more in balance this interdependency becomes, the greater are the opportunities to develop supplementary resources contained within the sii'da territory. Pasture is the most critical factor, and it is absolute rights to pasture, i.e. land in a broad sense necessary to maintain an optimal pastoralist adaptation, that facilitate the recurring modifications of number of reindeer in relation to personnel, considering seasonal variations as well as variations over longer periods of time due to changing climatic conditions.

Even such a view is determined by custom; the sii'da council reconsidered at regular intervals the special requirement for each separate family group in connection to the personnel of the household unit. Thereby it was possible at all times to distribute all resources available within the sii'da territory among its members in an equitable way.

According to customary law, natural barriers, such as mountain valleys, water courses etc, separated one sii'da territory from another. In their own ecological adaptation the Sámi both respected these boundaries and acted in accordance with them. The members of a sii'da had sovereign rights to all natural resources they utilized within its boundaries. In this respect the Sámi possessed stronger rights than others who might also be living in the sii'da territory. In some areas, such as Kemi in Finland e.g., hunting of wild reindeer and beaver was reserved for the Sámi. (TEGENGREN, 1978). This legal order of sii'da territory is based on custom and ancient usage. And, as Erik Solem has maintained, the control of territory need not be identical with ownership right. (SOLEM, 1933). To the Sámi it has always been essential to claim sovereign, unassailable rights to pasture reindeer, to hunt and to fish, etc; by comparison, ownership rights to a delimited area of land contains little meaning for them. Compare the demands actualized by the Cree and the Inuit in the James Bay negotiations. In a most exacting negotiation vis-a-vis the authorities, hunting and trapping rights, which are regarded as necessary requirements to maintain a particular way of life, not ownership rights to definite areas of land, represented on this occasion, the ultimate political goal for the native people.

However, the rights of usage are so qualified that they come close to ownership rights as legal entity. In order to gain rights of usage, which are sufficiently strong, their primary interest, the Sámi may even be compelled to obtain a form of ownership rights for the group. According to Otto Jebens it is moreover possible to argue that long-term utilization and actual occupation of the land, showing cultural continuity, will eventually establish ownership rights for the group as a whole vis-a-vis any other contending party. (JEBENS, 1983). This transformation of the legal order of territorial rights becomes more urgent to the Sámi as they experience a growing conflict of interests resulting from intensified contact with various levels of the larger society.

When it comes to Sámi usufructuary rights, the Supreme Court maintains that its verdict in the Taxed Mountains Case affirms the right of usage the Sámi already possess, and that this right is equally strong as is ownership right (HD, 1981). There is only one objection to this statement, and that is that such a right does not protect against expropriation by the state; thereby the right of usage does not offer the Sámi any "plus-rights" qua aboriginal people, regardless of how qualified this right may be. In order for Sámi to acquire a real position of negotiation, properly codified land rights must be ascribed to them, rights which go far beyond the strong usufructuary right previously defined according to the Reindeer Management Laws (See e.g. RNL, 1971). If this were not the case it would have been completely unwarranted for the Sámi to carry out the lengthy Taxed Mountains Case. It is also for this reason that the land rights issue has such a central place in the on-going work of the Sámi Rights Committees.

These claims for land rights emanate from the Sámi core areas. If the Sámi want to pursue a claim for aboriginal rights on this sensitive point, the claim cannot be restricted in legal terms to certain sections in the system of laws of the nation, for example Sveriges Rikes Lag or Norges Lover, and it is exactly in this perspective that the significance of Sámi customary right should be viewed.

The preliminaries to the Sámi Codicil from the 1740 's, as well as the very text regarding this important document of 1751 (Codicil to the Border Treaty between Sweden and Denmark/Norway), point in the same direction. To a great extent the Codicil 
confirms for the first time that Sámi have customary right to land and water and that this right is ascribed as a collective right. A community in one form or another, preferably siid $a$ although this term is not used in the text, is considered the owner of the rights at stake. This connection between the Codicil, as one instrument for legal codification, and Sámi customary right constituted a vital point for the Sámi in their tactics for the Taxed Mountains Case.

Pursuant to principles of customary law this right implies in part the attainment of sovereign right to land, in part title to land. Thereby it is understood that the sovereignty the Nation-State successively acquired also in Lapland could not lead automatically to a transfer of title to land from the Sámi to the state, nor to state ownership rights over territories conceived of as Sámi core areas. On the contrary, the implication is that the land ought to remain in the hands of the people who traditionally had made use of it and that this "ownership right" should be retained jointly by the group, not individually (Cf. SUNDBERG, 1979). The very demands of the state for sovereignty leading to self-ascribed ownership right to land implied what properly could be named internal colonialism (HECHTER, 1975), i.e. an act reflecting use of power which to a large extent neglected customary right, a legal conception which long had been established and incorporated in international law (This argument is also supported by KORPIJAAKKO, 1985).

The Sami Codicil of 1751 and the rights closely specified therein represent a sort of intermediate phase in the transient process from customary right to a legal situation which is more and more constrained to legislative measures. The Codicil stands as the first codification of Sámi rights chartered by the state authorities. That which should be guaranteed by this document was unbroken continuity of Sámi rights based on ancient usage and old custom; these were rights to use of land and water to reindeer pasture, hunting and fishing. Moreover, the Codicil states clearly that the local community is bearer of the rights in question which were to be exercised in both countries.

Obviously, the Codicil did not refer to newly established rights but instead confirmed ancient Sámi rights which were not to be curtailed or extinguished as a result of the border treaty between Sweden and Denmark/Norway. Because of that the Codicil is a legal document which is rather unique, both in historical perspective and in reference to our own time, compared to most other documents of legal nature regarding the Sámi. Under provision of this document a national border became irrelevant to a specific ethnic group, who since time immemorial had carried on a distinct way of life in the two nations included in the treaty. Therefore, the Codicil actually gives an example of a most foreseeing pol- icy anchored to older legal conceptions in which customary law had a far greater place than it has today. The process of legislation appearing later on in historic time has occasioned special laws and regulations which in no way codify any land rights. By these laws the Sámi are granted monopoly rights to herding reindeer and qualified usufructuary rights to land and water, but only to a limited extent are their land rights protected against external intrusion and pressure. And it was primarily such incongruities concerning rights in principle that the Sámi wanted to remedy by means of a court case of such magnitude as the Taxed Mountains Case.

Consequently, in the legislation there is very little basis for clarification of the Sámi land rights issue. Because the courts recently have proved unwilling to give guide lines for binding legal codification of land rights, the Sámi have every reason to express particularly high expectations for the Sámi Rights Committee presently at work. By means of the recent process of litigation the legal foundations on which the relatively strong Sámi usufructuary rights are based have been made clear; they rest on rights of immemorial usage, urminnes hävd, not on any diffuse idea of some kind of Sámi privilege (HD, 1981, HR, 1968, The Alvevatn Case). For a more elaborate argumentation in terms of legal history on this point see especially KORPIJAAKKO, 1985 and CRAMÉR, 1986.

Finally, international law constitutes a formal link between customary right and the nation's official system of laws.

Principal legal views deriving from customary right are here clothed in a juridical polish which is fully acceptable and respected in contemporary legal contexts, for they form an integrated part of the entire body of laws.

International law proposes protection of the material basis of each distinct ethnic group, enabling it to uphold its special way of life. Following these principles a sufficient amount of land which is used in a traditional manner must be preserved intact; otherwise - the ethnic minority group cannot continue to exist as a particular people. International documents such as the UN Declaration Against Racial Discrimination 1966 and the European Convention concerning Human Rights 1950 both support these ways of thinking. In all cases where aboriginal people are stating claims for improved land rights, these two central documents are now cited.

The material basis for cultural perpetuation is wholly dependent on firm land rights. Most aboriginal peoples around the world do not presently possess such land rights; for this reason their ethnopolitical position remains rather weak in all conflicts of interest. The question of reinforced right of self-determination with respect to the utilization of resources is crucial in this connection. 


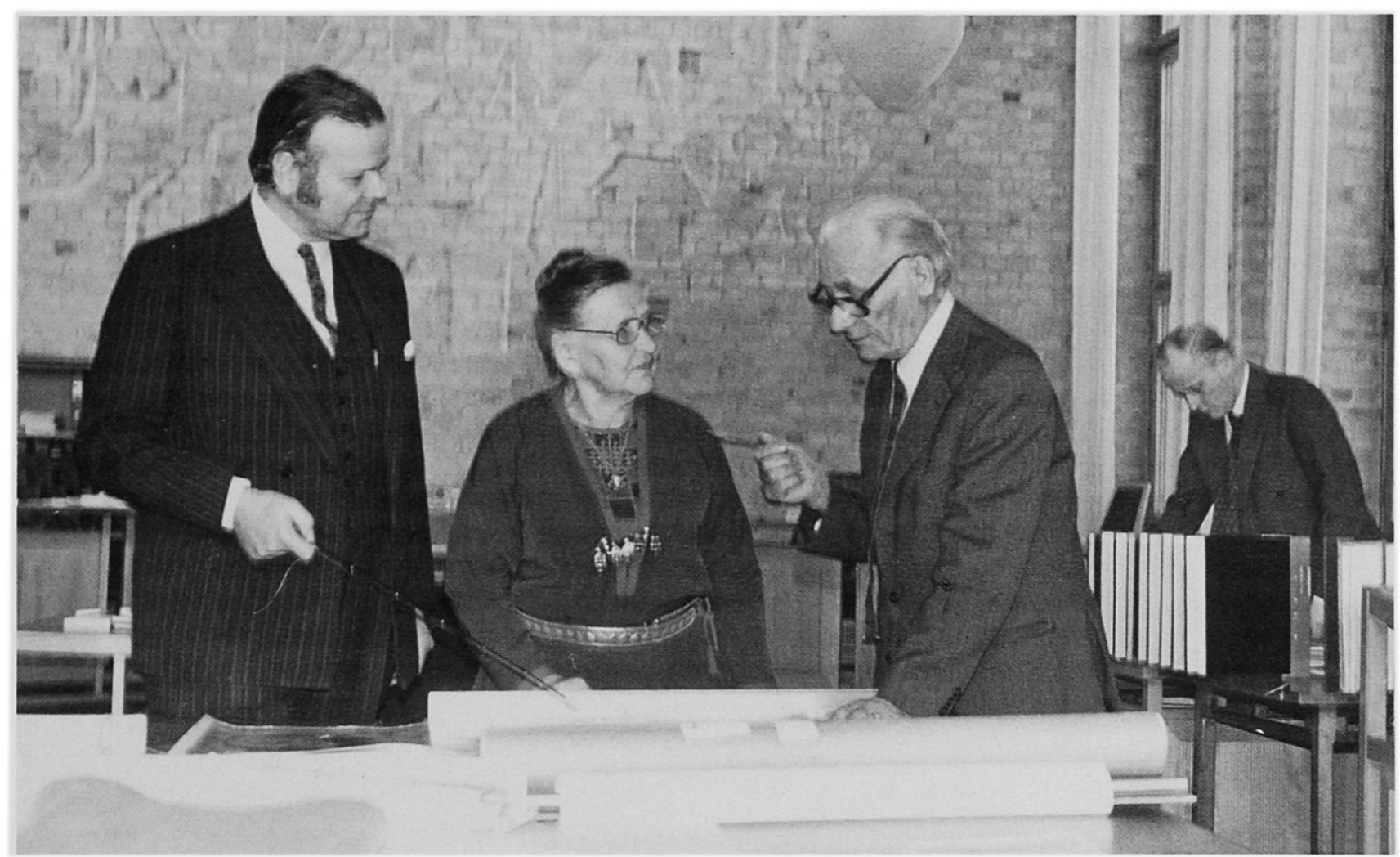

Fig. 2 Many decisive questions concerning Sámi rights have lately been actualized by means of litigation. The picture was taken during the hearing of the Taxed Mountains Case in the Court of Appeal in Sundsvall 1976. From left to right we see the Sámiombudsman, one South Sámi who attended as spectator, a key expert witness, himself a Sámi and professor in Sámi linguistics, and the legal counsel representing the Crown. (Photo: Tom G. Svensson)

In conclusion we may point out that the Sámi codicil of 1751 , unlike other legal documents, unites principles related to international law with those based on Sámi customary law. This connection makes the Codicil unique in our time; thereby it is constantly topical, being useful in the most diverse confrontations of interest.

Ownership rights to land are founded primarily on the use of land and occupation. John Cave has defined three minimum criteria for obtaining title to land. (CAVE, 1982):

1. right to use land

2. right to exclude others from land

3. right to dispose of land

Transferred to the Sámi case we may state that the right to use is adequately strong as it is today, whereas the right to exclude others is constrained to reindeer herding. The right to dispose of land seems less interesting, as it is far more important to secure all the land still available. For the future it is vital that the right to exclude others, including the state, is strengthened considerably.
The remaining land has to be secured for future generations of Sámi; at the same time efficient control of current utilization of resources is required.

To aboriginal peoples land has never constituted a market commodity, right to alienate, therefore, is irrelevant. On the other hand, cultural viability is dependent on firm land rights, so that the Sámi are able to develop a versatile and differentiated economy in the core areas of Sámi habitation.

\section{Aboriginal rights}

At this point it may be useful to delineate the concept of aboriginal rights more precisely. The economy of aboriginal people is, as a rule, characterized by different forms of landbased subsistence activities. As encapsulated entities within the structural framework of the Nation-State, it is necessary for native peoples

1. to be able to refer to a landbase and

2. to exercise jurisdiction over their own territories (cf. ASCH, 1984). 
Based on these two prerequisites the contents of aboriginal rights becomes culturally meaningful and not only a juridical phraseology. To establish and maintain a land base implies that native people either have a kind of ownership right to land or that they can plead a right to hunt, fish and trap. Right of self-determination, i.e. the ethnic minority's ability to manage this land base without external intervention by means of its own council is considered equally important in acquiring aboriginal rights. By this means people can control the access to their own natural resources.

The close connection between a land base and selfdetermination, however, points to certain barriers inhibiting progress in the struggle towards establishing aboriginal rights. Without acknowledgement of aboriginal rights, it is impossible to demand firm land rights, for claims are not seen as legitimate. On the other hand it seems impossible to have the status as an aboriginal people clarified and confirmed unless it is based on firm land rights. One precondition for the ethnic minority in its struggle to prevent assimilation is recognition of its more or less selfevident aboriginal rights. In Scandinavia the Sámi have so far had no breakthrough in their presistent efforts; neither do the very restricted guiding principles for the Sámi Rights Committees give much reason for optimism.

\section{The question of subsistence}

Among many aboriginal peoples subsistence is the predominant form of economy; for this reason this phenomenon deserves special notice. Lately subsistence has gained special attention as an increasing number of native peoples are presently pleading for their ancient right to a subsistence economy as one decisive factor in their continuous struggle to survive culturally. Commissioned by the Inuit Circumpolar Conference the renowned judge Tomas Berger has recently presented a penetrating review of the Alaska Native Land Claims Settlement Act from 1971. In his report Berger makes the idea of subsistence one of the main points in his proposal for changes he deems necessary if the native people in Alaska are to be given a fair chance to continued cultural existence (BERGER, 1985).

To be able to pursue a subsistence economy certain cash income is required; in other words subsistence should not be viewed as a form of economy entirely without money. The cash element is not emphasized, however, but often it is reduced to a requisite asset in maintaining a particular way of life based on subsistence activities. This condition applies to several Inuit groups as well as the reindeer pastoralist Sámi and many other aboriginal peoples. Primarily it is the use of modern technol- ogy in their ecological adaptation which makes it necessary for them to obtain a constant flow of cash. In order to cover the costs of production of the subsistence economy a sufficient amount of cash must be secured. Such a clarification of subsistence economy is important, because a great deal of misunderstanding is flourishing; for instance, the authorities tend to question whether people actually carry on subsistence economy or not when cash is present.

In Alaska substantial research which supports the general argument above has recently been carried out. There, many local communities have developed what is called "mixed, subsistencebased socioeconomic systems", the main objective of which is to sustain subsistence hunting and fishing (e.g. WOLFE and ELLANNA, 1983; FALL, 1985). The remarkable increase in the number of those actively taking part in traditional wildlife harvesting among the Cree, as one of the consequences derived from the Cree Hydro-Quebec Agreement of 1975, is also worth noting (FEIT, 1982a. 1982b).

The question remains though, does subsistence has anything to do with land rights? Certainly subsistence has an impact on land rights in the sense that the latter means very little if an ethnic minority is not able to continue to exercise traditional resource development on its land. Prohibition against seal hunting for the Inuit, for example, renders their land rights fairly devoid of content (WENZEL, 1985). One prevalent problem for the native peoples is that the system of laws of the larger society has not provided adequate protection either of their land or of their subsistence economy. In consequence, for each separate indigenous people the primary ethnopolitical goal will be geared towards the attainment of improved land rights, an indispensable development if the economic base of the minority is to be satisfactorily strengthened. Cultural viability is sustained by an economic base which is well-entrenched as well as adaptive to changing conditions. The extremely vulnerable subsistence economy presupposes empowered control of territory; in different circumstances the economic base of the native people as well as its way of life will be undermined (See also BERGER, 1985 who gives a more penetrating analysis of the connection between land rights and subsistence).

\section{Definition of the claims and the problems of communication}

To people recognizing a new and extended affinity within the frame of the Fourth World the right to their ancestor's land emerges as a superordinate issue. For aboriginal minorities this right appears as self-explanatory, whereas the position of the major- 
ity societies is more ambivalent. The right itself can certainly be acknowledged by the larger society on a formal basis; how the actual contents of this right is conceived, however, may differ strikingly between the larger society and the ethnic minority. In order to arouse enough attention and understanding for its demands, the relatively powerless minority must politicize these demands. This means, among other things, that the minority will act unpredictably, thereby markedly offending against set rules of conduct appropriate to certain situations governed by the authorities and in this manner attempting to accentuate the legitimacy of its land rights claims. When the Sámi put a tent, láwo, directly in front of the House of Parliament, Stortinget, in Oslo and began a hunger strike in protest against the Alta development in 1979, this action was both quite unexpected and extremely effective. By this action the Sámi demonstrated a new form of articulation aiming at constrasting effect; i.e. they chose to communicate cultural diversity at the same time as they alluded to a moral right to their own land (PAINE, 1984). Marking of the ethnic boundary stands as a particularly important factor in the constant struggle for strong, indispensable land rights by aboriginal people. It is only by virtue of the weight laid on cultural difference that the land rights claim becomes legitimate; the minority is, as a rule, solely responsible for this marking of diversity.

As is usually the case at dividing lines between cultures, there are problems of communication which have to be overcome. In ethnic minority situations where the two interacting parties in no way appear as equals, this remains an appreciable dilemma. For instance, in the very comprehensive Taxed Mountains Case the Sámi encountered great difficulties in their attempts to communicate well-founded arguments for land rights based on both legal history and culture history. Similarly, the Sámi culture specific actions and unequivocal marking of their cultural distinctiveness seemed to fall into a social vacuum; quite simply they did not reach all the way to the intended receiver, i.e. primarily the members of the court. Certainly, the Sámi game was allowed to continue as a kind of interethnic relation without any interference to speak of. However, vis-a-vis the courts the Sámi had limited success in trying to convert the court case into a cultural discourse. The court decisions on all levels give clear evidence of that.

Even if the non-legal argumentation lacks direct power to influence, the same idea reinforces the Sámi legitimate right to their land. In a land rights contest as comprehensive as the Taxed Mountains Case it would be completely pointless to pursue a plea which is based only on narrow juridical premises, in this case rights of landed property. Consequently, in this type of confrontation the meaning of a comprehensive, culture specific form of communication ought not to be underestimated.

\section{A final remark}

Land rights is a relative concept. The meaning and value of these rights may be annihilated by external circumstances, beyond the control of the individual state, irrespective of how firmly the Nation-State is prepared to ascribe land rights to an indigenous minority group. Most land based ethnic minorities are seriously concerned about this predicament, although the problem as such does not only refer to them. Banishment of seal hunting together with establishment of a quota for hunting large sea mammals, such as whale and walrus, which is too narrow, will drastically reduce the import of hard-won land rights. This new form of conflict of interest is generated by growing pressure on the state governments exerted by supra-national wildlife and environmental movements. The frequently quoted expression: "Our land is our life" emphasizes very clearly and with exemplary concentration what this is all about.

As far as the Sámi are concerned, their crucial reindeer pasture, especially winter pasture based on lichen, is now threatened by complete devastation as a result of radioactive fall-out from the nuclear power plant disaster in Chernobyl. Without overreacting we may state that the Sámi with reindeer pastoralist adaptation hereby are facing their most demanding problem so far. Their way of life is particularly vulnerable; it is maintained by experts that reindeer-lichen absorbs and stores radioactive wastes in especially high doses compared to other ground vegetation. In large parts of the reindeer pasture area prohibition against reindeer meat was immediately decreed. The implication of such a decision is that the economic base of very many reindeer Sámi will be eliminated; it is still uncertain for how long they will be unable to get any revenue from their primary means of production. This new problem is especially felt in the southern region of reindeer Sámi habitation in both Norway and Sweden. Furthermore, for reasons of health the Sámi must abstain from consumption of all sorts of reindeer meat for an indefinite period of time, a severe interference with ancient Sámi food culture, in which reindeer meat prepared in endless varieties constitutes their every day staple food. To large groups of Sámi, therefore, the future seems extremely gloomy, because it is so far uncertain as to how many years it will take before a prohibition against reindeer meat can be nullified. A feeling of optimism for the future expressed by many young Sámi in the years preceeding the Chernobyl disaster has also suffered a serious blow. Should several more nuclear power plant disasters occur, which by unfavorable conditions respecting wind and precipitation may affect Northern Scandinavia, the implications would be devastating, not the least from a point of view of cultural survival. 
In no way do firm land rights imply any guarantees against such ecological catastrophes which have far reaching consequences for the culture. Naturally this does not mean that the Sámi and other commensurable ethnic groups should not henceforth carry the issue for improved land rights further. In order to strengthen the culture and make it more viable generally speaking, such policy is both obvious and imperative. However, it should be quite clear that the question itself is so complex that all problems are far from being resolved by means of land rights. But in order to negotiate just and full compensation regarding disasters of this magnitude improved land rights are indispensable. The Sámi engagement in the land rights issue was further manifested at the National Meeting held by the Swedish Sámi in June 1986. During that meeting the significance of strong land rights was stressed emphatically: "The new survival of the Sámi both as a people and as a culture is intimately connected to Sámi rights to land and water to the ways in which the natural resources in Sápmi are utilized (SSR/XL II National Meeting Resolution A).

In the last National Meeting in June 1988 one of the Chief Justices of the Swedish Supreme Court gave a most welcome speech from a Sámi point of view. Based on a thorough rethinking of the comprehensive Taxed Mountains Decision (HD, 1981) he urged firmly the Sámi Rights Committee to suggest fundamental revisions of the legal position of the Sámi concerning their rights to land and water. According to his conviction the Sámi should be provided with a limited right to veto, or at least a right to prevent planned exploitation temporarily in order to bring about extensive pre-studies examining socio-cultural consequences as a minimum strengthening of their legitimate rights. These new headways pointing to new legislation prove that the time exhaustive legal strategy the Sámi have been engaged in in later years has not been to no purpose.

Moreover, in their most significant resolution from the same meeting (Resolution A, SSR 1988) the Sámi conclude by stating that they must be assured rights of decision making in their own affairs, rights which are based on immemorial usage to their land and on international law, and, most importantly, these comprehensive rights must be constitutionally protected.

\section{Zusammenfassung}

Die Frage der Landrechte scheint die Hauptrolle in den heutigen ethnopolitischen Prozessen in der sogenannten Vierten Welt zu spielen. Da Landrechte auch eng mit ökologischen Aspekten verknüpft sind, werden sie zur Basis für das kulturelle Überleben vieler indigener Minderheiten. Deshalb ist die Verbesserung der Land- und Wasserrechte eine der ersten politischen Forderungen für viele indigene Völker. In diesem Artikel wird das Konzept der Landrechte diskutiert und es werden verschiedene Strategien dargelegt, wie sie von einer ethnischen Minderheit, den Sámi im nördlichen Skandinavien, benützt werden. Dabei werden Lösungsvorschläge, wie sie bei interethnischen Konfrontationen in dieser grundsätzlichen Problemstellung auftreten, besonders betont.

\section{Literatur}

ASCH, M. (1984): Home and Native Land. Aboriginal Rights and the Canadian Constitution. Methuen, Toronto.

BERGER, T. (1985): Village Journey. The Report of the Alaska Native Review Commission, Hill and Wang, N.Y.

CAVE, J. (1982): The Gitksam Traditional Concept of Land Ownership. Anthropologica Vol. XXIV.

CRAMÉR, T. (1986): Samernas Vita bok. Volym 22, Tärnaby.

FALL, T. (1985): Historical Changes in Hunting and Fishing Patterns in the Copper River Basin, Alaska. Paper AAA, Annual Meeting, Washington D.C., 1985.

FEIT, H. (1982a): Protecting Indigenous Hunters: The Social and Environmental Protection Regime in the James Bay and Northern Quebec Land Claims Agreement, in Charles Geisler et. al. eds., The Social Impact Assessment of Rapid Resource Development on Native Peoples. Indian SIA Univ. of Michigan.

FEIT, H. (1982b): The Income Security Program for Cree Hunters in Quebec: An Experiment in Increasing the Autonomy of Hunters in a Developed Nation State. Canadian Jrl. of Anthr. Vol. 3 No. 1.

HECHTER, M. (1975): Internal Colonialism. The Celtic Fringe in British National Development, 1536-1866. Routledge \& Kegan Paul, London.

HÖGSTA DOMSTOLEN, HD. (1981): Dom i Skattefjällsmålet Nr. DT 229 Januari 1981, Stockholm. Reprinted in B. Jahreskog ed. The Sámi National Minority in Sweden, Almquist \& Wicksell/Humanities Press, Stockholm - N.Y. USA.

JEBENS, O. (1983): Samenes Land - En Rettslig Realitet? Tidsskr. for Rettsvitenskap Arg. 95, Hefte 4.

KORPIJAAKKO, K. (1985): Samerna och jordäganderätten 1-2 Diedut No. 3, Sámi Instituhtta, Kautokeino.

PAINE, R. (1972): The Herd Management of Lapp Reindeer Pastoralists. Jrl. of Asian and African Studies Vol. VII.

PAINE, R. (1984): The Claim of the Fourth World in Native Power, The Quest for Autonomy and Nationhood of Indigenous Peoples. Jens Brøsted et al. eds.

PRAWITZ, G. (1966-67): Samernas Skattefjäll. Domstolsinlaga, Stockholm.

RNL, 1971, Rennäringslagen 1971. Stockholm. 
RUONG, I. (1937): Fjällapparna i Jukkasjärvi socken, Geographica Nr. 3, Uppsala.

SÁMI CODICIL (1751): Codecill till Gränse Tractaten emellan Konunga Rikerne Swerige och Norge, Lappmännerne beträffande reprinted in T. Cramér G. Prawitz Studier i renbeteslagstiftning, Norstedt \& Söners, Stockholm.

SOLEM, E. (1933): Lappiske Rettsstudier. Instituttet for Sammenlignende Kulturforskning, Oslo.

SUNDBERG, J. (1979): Customary Law in Sweden and the Sámi Minority. Inlaga till HD, Stockholm.
TEGENGREN, H. (1978): Samernas i Kemi Lappmark rätt till bäverfänge i K. Bergsland red. Samenes og Sameområdenes rettslige stilling historisk belyst. Universitetsforlaget, Oslo.

WENZEL, G. (1985): Marooned in a Blizzard of Contradiction: Inuit and the Anti-Sealing Movement. INUIT Studies Vol. 9 Nr. 1.

WOLFE, R. and L. Ellanna (1983): Resource Use and SocioEconomic Systems: Case Studies of Fishing and Hunting in Alaskan Communities. Alaska Dept. of Fish and Game Division of Subsistence. Technical Paper No 61. Juneau. 